\title{
Zoofilia e raiva. Estudo de um caso de infecção pelo rabidovírus, adquirido através de comportamento parafílico
}

Sérgio José Alves de Almeida*

Diderot Rodrigues Parreira**

Naila Alves***

\section{RESUMO}

O presente estudo de caso foi realizado na Faculdade de Medicina de São José do Rio Preto (FAMERP).

Em março de 1997, deu entrada no Hospital de Base, paciente masculino, 26 anos, trabalhador rural, apresentando como queixa principal dificuldade para engolir há mais ou menos seis dias. O quadro clínico apresentava disfagia progressiva, sialorréia abundante, hidrofobia, acrofobia a alterações de comportamento cursando com agressividade a nervosismo. Os dados da avaliação neurológica acrescidos da história sexual (zoofilia) levaram a hipótese diagnóstica de um quadro de raiva. O óbito ocorreu seis dias após a internação, aparecendo edema cerebral de causa não esclarecida como causa mortis.

\footnotetext{
* Professor adjunto doutor da Faculdade de Medicina de São José do Rio Preto (FAMERP).

** Terceiranista da graduação da FAMERP.

*** Terceiranista da graduação da FAMERP.

Recebido em 13.09.97

Aprovado em 26.09.97
} 
Amostras enviadas ao Instituto Pasteur onde foi realizado a imunofluorescência direta, tiveram resultados positivos para o antígeno rábico, fechando o diagnóstico.

\section{INTRODUÇÃO}

Zoofilia constitui um termo alternativo para Zoorastia (do grego zoon $=$ animal e erastes $=$ amante $)$ e indica excitação ou satisfação sexual através do contato com um animal (Goldenson e Anderson).

Essa forma de relacionamento é freqüente nas áreas rurais a pequenas comunidades, fazendo parte do cotidiano de muitos jovens pré-púberes e adolescentes.

A raiva (do latim rabies), também denominada hidrofobia, é uma moléstia infecciosa aguda, causada por um vírus neurotrópico que determina quadro característico de encefalomielite. Todos os animais de sangue quente são susceptíveis ao vírus da raiva, mas os canídeos são os que mais frequientemente as transmitem ao homem através de mordeduras.

O caso em questão foi estudado na Faculdade de Medicina de São José do Rio Preto (FAMERP) em seu Hospital de Base a envolve um paciente do sexo masculino, adulto, que foi a óbito após haver contraído o vírus da raiva através de zoofilia.

\section{RELATO DO CASO}

\section{I - Identificação}

A. F. S., masculino, 26 anos, branco, solteiro, trabalhador rural, procedente de Avanhandava.

\section{II - Queixa Principal}

Dificuldade para engolir há mais ou menos seis dias.

\section{III - História Pregressa Moléstia Atual}

Paciente refere que vinha bem até há aproximadamente 12 dias, quando passou a apresentar dor de forte intensidade no braço esquerdo que se irradiava para o hemitórax do mesmo lado. Concomitantemente hipoestesia e dificuldade para conciliar o sono. 
Sem queixas de cefaléias, tonturas, vômitos ou desmaios.

Há mais ou menos seis dias teve início quadro de disfagia progressiva, acompanhada por sialorréia abundante, hidrofobia a alterações de comportamento, como agressividade a nervosismo.

Há mais ou menos dois dias procurou serviços médicos em sua cidade de origem, permanecendo internado, mas não obtendo qualquer melhora. Foi então transferido aos serviços do Hospital de Base de São José do Rio Preto. Acompanhantes referem espasmos musculares involuntários, principalmente na face.

\section{IV - Informações Pesquisadas}

Nega febre, tosse, dispnéia ou cefaléia;

Refere a emagrecimento e indisposição geral;

Nega dor abdominal e alterações intestinais;

Nega náuseas, vômitos e icterícia;

Nega alterações urinárias;

Nega lombalgias e artrites;

Refere parestesias e insônia.

\section{V - Exame Físico}

PC: 100 bpm; PA: 130X80; 51 quilos; $1,77 \mathrm{~cm}$.

Paciente em REG, agitado, orientado no tempo e espaço, consciente, acianótico, aniquitérico, afebril, corado, hidratado e emagrecido.

Pulmões MV mantido bilateralmente, sem ruído adventício.

Precordio RDR sem sopro

\section{$\mathrm{BNF}$}

Abdômen - plano, tenso (contração do músculo reto abdominal), sem víceromegalias e RHA positivo.

\section{VI - Exame Neurológico}

Presença de espasinos musculares;

Ataxia de marcha;

Arreflexia generalizada;

Agitação psicomotora;

Presença de rigidez de nuca.

\section{VII - História da Vida Sexual}

Paciente refere manter relações sexuais com animais, basicamente cachorros, havendo diversidade de animais.

\section{VIII - Hipótese Diagnóstica: RAIVA}




\section{DISCUSSÃO}

Uma vez estabelecido o quadro clínico, não existe tratamento específico, ocorrendo o óbito alguns dias após a internação hospitalar. Como causa mortis aparece edema cerebral de causa não esclarecida.

A necropsia realizada pelo Serviço de Verificação de Óbito (SVO) da Faculdade de Medicina de São José do Rio Preto (FAMERP), na tentativa de confirmar o diagnóstico de Raiva sugerido pelo quadro clínico, nos forneceu como achados macroscópicos edema cerebral difuso e herniação de amígdalas cerebelares. A microscopia revelou congestão passiva generalizada.

Amostras de cérebro, cerebelo, medula espinhal e bulbo foram enviadas ao Instituto Pasteur onde foi realizada a imunofluorescência direta a fim de pesquisar o antígeno rábico. $\mathrm{O}$ resultado em todas as amostras foi positivo, fechando portanto o diagnóstico de raiva.

BURDMANN e TIRIBA (1995) nos trazem: "A inoculação traumática pela mordedura é o mecanismo habitual. Entretanto, em cerca de um terço da casuística, falta a referência de mordedura. Imagina-se, nessas condições, outra forma de exposição à principal matéria contaminante, a saliva: contato bestial (zoofilia), beijos, alimentação boca a boca, aerosol de partículas atmosféricas de alta densidade viral, infeção laboratorial, acidente vacinal, contato com morcegos e outros animais silvestres".

RODRIGUES JR. (1995) analisa muito bem as relações zoofílicas existentes entre adolescentes e adultos jovens com animais domésticos como cães, galinhas, éguas, porcas etc.

FUCS (1985) já havia abordado o tema quando analisa comportamento sexual em área rural.

No presente estudo o paciente relata manter contatos sexuais com cachorros, vários deles, mas não informa exatamente a maneira como estes aconteciam (oral, penetrativo ativo ou passivo, masturbatório, etc.).

Não há qualquer indicação durante sua permanência em hospital de que haja relatado ataque por parte de qualquer dos animais ou haver sofrido alguma forma de mordedura.

Os cães envolvidos, que puderam ser identificados, foram retidos em observação.

De acordo com os conceitos teóricos sociais o paciente também provinha de área rural, não tendo companheira fixa.

Reuniões interdisciplinares realizadas na FAMERP concluíram que o contágio se deu através do contato sexual. 


\section{REFERÊNCIAS BIBLIOGRÁFICAS}

1. AMATO Neto, V.; BALDY, J. L. Doenças transmissíveis. São Paulo, Sarvier, 1989.

2. BURDMANN, L.; TIRIBA, A. Raiva humana, compacta infectológica, $\mathrm{n}^{\circ} 8$, 1996.

3. FUCS, G. Por que o sexo é bom? Espaço a Ternho, Rio de Janeiro, 1985.

4. GOLDENSON. R.; ANDERSON, R. Dicionário de sexo, Ática, São Paulo, 1989.

5. RODRIGUES JR., O. M. Psicologia e sexualidade. MDSI, Rio de Janeiro, 1995.

6. VERONESI, R.; FOCACCIA, R. Tratado de infectologia. São Paulo, Atheneu, 1996. 